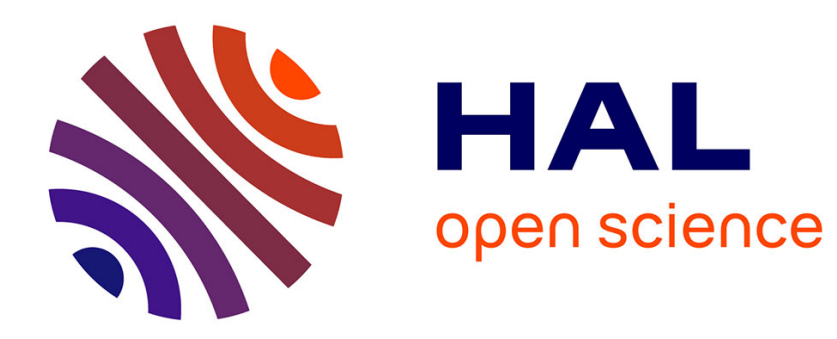

\title{
Testing the Technology Interpretation of News Shocks
} Bernd Lucke

\section{To cite this version:}

Bernd Lucke. Testing the Technology Interpretation of News Shocks. Applied Economics, 2011, 45 (01), pp.1-13. 10.1080/00036846.2011.566209 . hal-00732114

\section{HAL Id: hal-00732114 https://hal.science/hal-00732114}

Submitted on 14 Sep 2012

HAL is a multi-disciplinary open access archive for the deposit and dissemination of scientific research documents, whether they are published or not. The documents may come from teaching and research institutions in France or abroad, or from public or private research centers.
L'archive ouverte pluridisciplinaire HAL, est destinée au dépôt et à la diffusion de documents scientifiques de niveau recherche, publiés ou non, émanant des établissements d'enseignement et de recherche français ou étrangers, des laboratoires publics ou privés. 


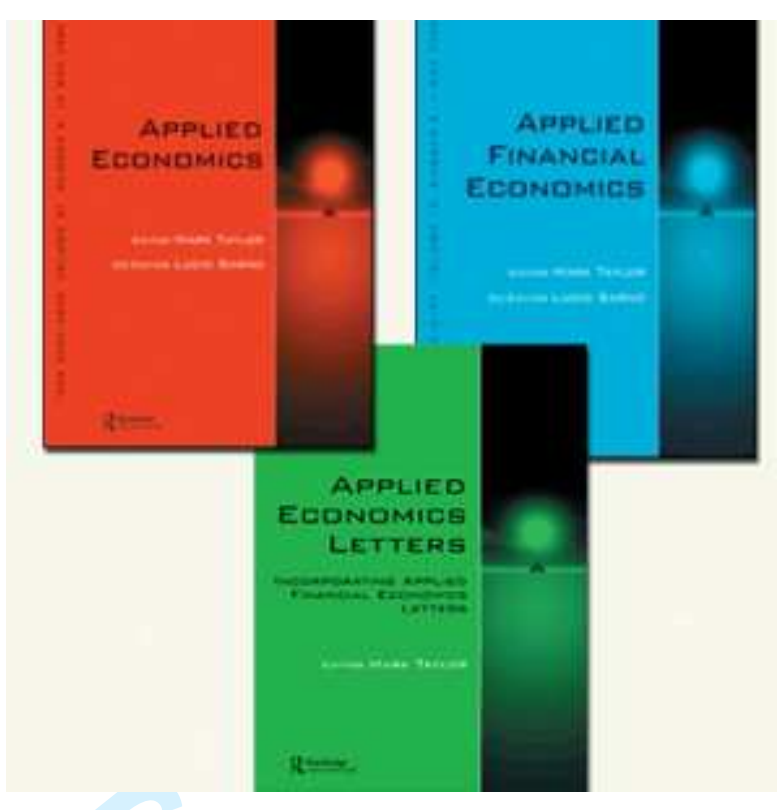

Testing the Technology Interpretation of News Shocks

\begin{tabular}{|c|c|}
\hline Journal: & Applied Economics \\
\hline Manuscript ID: & APE-2010-0251 \\
\hline Journal Selection: & Applied Economics \\
\hline $\begin{array}{r}\text { Date Submitted by the } \\
\text { Author: }\end{array}$ & 21-May-2010 \\
\hline Complete List of Authors: & Lucke, Bernd; UNiversity of Hamburg, Economics \\
\hline JEL Code: & $\begin{array}{l}\text { E32 - Business Fluctuations|Cycles < E3 - Prices, Business } \\
\text { Fluctuations, and Cycles < E - Macroeconomics and Monetary } \\
\text { Economics }\end{array}$ \\
\hline Keywords: & Business cycles, News \\
\hline
\end{tabular}

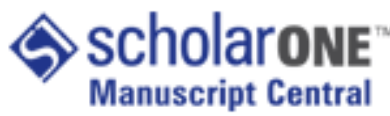




\title{
Testing the Technology Interpretation of News Shocks
}

\author{
Bernd Lucke ${ }^{1}$
}

May 2010

\begin{abstract}
:
This paper presents further evidence on the hypothesis of news driven business cycles. I use a structural VECM approach to identify news shocks as in Beaudry and Lucke (2010). I document three facts: First, news shocks identified by BL are Granger-causal for US patent data. Second, BL's analysis applied to German macro data reveals very similar patterns: Activity is largely driven by news and news shocks explain a sizable and increasing share of TFP variance at long horizons. Third, German news shocks are Granger-causal for German patent data and the pattern is, again, very similar to the US. Since patent data in the US and Germany are almost uncorrelated, the similarity is striking and strongly suggests a technology interpretation of news shocks.
\end{abstract}

JEL: E32

Keywords: News driven business cycles

\footnotetext{
${ }^{1}$ Department of Economics, University of Hamburg, von-Melle-Park 5, D-20146 Hamburg, Germany, email: lucke@econ.uni-hamburg.de
} 


\section{Introduction}

New hypotheses about driving forces of business cycles have emerged in recent years. Traditionally, either the real business cycle (RBC) or the New Keynesian paradigm have dominated the views on what kind of shocks might be the major causes of medium-run fluctuations in aggregate economic activity. Consistent with the former, Shapiro and Watson (1988), King et al. (1991) or Galí (1992) found a dominant role of supply shocks in the variance of output, while a perceived negative correlation of hours and technology shocks led e. g. Galí (1999), Francis and Ramey (2005) and many others to attribute most explanatory potential for business cycles to non-technology shocks.

Recently, however, Fisher (2006) and Beaudry and Portier (2006) have revived the debate by suggesting that technology shocks might not take the form of surprise shocks to total factor productivity (TFP), the workhorse of most RBC models. Fisher, following Greenwood, Hercovitz and Krusell (1997), distinguishes between shocks to disembodied and embodied technology. He finds the former to be unimportant indeed, but claims that shocks to investment specific technology (IST) are the major source of hours variance. Simultaneously, Beaudry and Portier (2006) suggest expectational shocks reflecting news about future technological developments as an important force behind macro fluctuations. Jaimovich and Rebelo (2009) present a formal model in which such shocks generate comovement between the main macro aggregates - a nontrivial issue, as Beaudry and Portier (2007) have shown.

Given various competing hypotheses about the major source of fluctuations in aggregate activity, Beaudry and Lucke (2010) (henceforth BL) use structural vector error correction models to identify alternative types of shocks and quantify their explanatory power for hours, output and investment. They find that news shocks (identified as shocks orthogonal to embodied and disembodied technology variables on impact) account for most of the observed forecast error variance in macroeconomic activity across different identification schemes, samples and sets of variables. They interpret the news shocks as technological since they find a significant long run response of TFP to news shocks. Also, news shocks account for a substantial share of TFP variance at longer horizons.

Given the seemingly important role of news shocks for aggregate activity, BL's interpretation of news as anticipation of technological advances deserves further scrutiny. There are at least three possibilities to test the technology interpretation of news shocks: First, if news are mainly news about future technology, then these news should be followed by an increase in the number of granted patents for inventions which develop or extend this technology. This implies that identified news shocks should be Granger-causal for patents. Second, technological news should not only affect US stock markets, but also affect the markets of other technologically advanced countries. Hence we should expect that the same identification strategy, applied to data of a different country should also uncover shocks which drive both activity and (in the lower frequencies) tfp. I will test this hypothesis with German data. Third, if German news shocks are news about technology, they should also be Granger causal for (German) patents. Since US and German patent data are virtually uncorrelated, this test should be hard to pass unless the technology interpretation of news shocks is indeed true.

The paper is organized as follows: Section II briefly reproduces BL's benchmark case. The structural residuals labeled "news shock" and data for granted patents are used to test for Granger causality (in both directions). Section III identifies news shocks in German macro data and assesses their impact on aggregate activity. Section IV is devoted to testing for a causal link between German news and patent data. Section V concludes. 


\section{News shocks and patents in the US}

BL study the relative importance of several candidate explanations of macroeconomic fluctuations in a setting which allows these shocks to compete. They use a structural vector error correction approach (SVECM) to isolate five shocks commonly discussed in the literature: Surprise changes to disembodied technology, surprise changes to embodied technology, news shocks, monetary policy shocks and preference shocks. They mainly work with a five-dimensional VECM composed of measured total factor productivity ( $t f p$ ), the inverse of the relative price of investment goods ( $p i)$, an index of stock prices ( $s p$ ), hours worked $(h)$, and the Fed funds rate (int). Intuitively, the reasons for choosing these variables are (i) measured TFP should largely be driven by shocks to disembodied technology, (ii) the relative price of investment goods should be an indicator of investment specific technological change $^{2}$, (iii) the value of stock prices should help isolate news about future technological developments, (iv) hours worked is a good indicator of aggregate activity, the main focus of business cycle analysis, and (v) the fed funds rate should help identify monetary policy shocks.

Collect these variables (in this order) in the vector $K$-dimensional vector $y_{t}$, i. e. $K=5$. Assume this vector is integrated of order one and can be represented as a vector autoregressive (VAR) process of order $p<\infty$. Allowing for $r>0$ co-integrating vectors, the error-correction representation of the process is given by

$$
\Delta y_{t}=\alpha \beta^{\prime} y_{t-1}+\sum_{j=1}^{p-1} \Gamma_{j} \Delta y_{t-j}+u_{t}
$$

where $\alpha$ and $\beta$ are $K \times r$ matrices of loading coefficients and co-integrating vectors, respectively, the $\Gamma_{j}$ 's, $j=1, \ldots, p-1$, are $K \times K$ coefficient matrices and $u_{t}$ are the reduced form error terms. These can be thought to be linear combinations of the structural shocks $\varepsilon_{t}$ whose covariance matrix is the identity matrix $I_{K}$. Since the covariance matrix of $u_{t}$ is nonsingular, there exists a nonsingular matrix $B$ such that $u_{t}=B \varepsilon_{t}$. This matrix is not unique and suitable assumptions must be imposed on its coefficients to identify it. The structural model, a $B$-model in the sense of Lütkepohl (2005), is then obtained from (1) by applying the Granger Representation Theorem:

$$
y_{t}=L \sum_{\tau=1}^{t-1} \varepsilon_{\tau}+B \varepsilon_{t}+\sum_{\tau=1}^{\infty} \Xi_{\tau}^{*} B \varepsilon_{t-\tau}+y^{0}
$$

where $y^{0}$ is a vector of initial conditions, $L:=\beta_{\perp}\left[\alpha_{\perp}{ }^{\prime}\left(I_{K}-\sum_{i=1}^{p-1} \Gamma_{i}\right) \beta_{\perp}\right]^{-1} \alpha_{\perp}{ }^{\prime} B$ is a $K \times K$ matrix with rank $K-r, \alpha_{\perp}, \beta_{\perp}$ denote orthogonal complements of $\alpha, \beta$, respectively, and the matrices $\Xi_{j}^{*}, j=1, \ldots, \infty$, are absolutely summable, i. e. $\lim _{\tau \rightarrow \infty} \Xi_{\tau}^{*}=0$. Hence, in terms of structural interpretation, $L$ is the long run multiplier matrix of the structural shocks $\varepsilon_{t}$ and $B$ is the corresponding short run impact matrix.

\footnotetext{
${ }^{2}$ This follows Fisher (2006).
} 
Identification of the structural shocks requires (at least) $K(K-1) / 2$ restrictions on $B=:\left(b_{i j}\right)$ and $L=:\left(l_{i j}\right)$, i. e. at least ten restrictions in the case of $K=5$. BL's benchmark identification imposes only few long-run restrictions since at least the three types of technology shocks may well cause permanent effects and should, therefore, be completely unrestricted in the long run. IST shocks are identified as orthogonal on impact to tfp and news shocks are identified as orthogonal to measures of both embodied and disembodied technology on impact. Monetary shocks are assumed to have no contemporaneous effect on economic activity, cf. e. g. Bagliano and Favero (1998). The "preference shock" is, in fact, very general, it is identified as any non-technology, non-monetary shock. For a detailed discussion of the identifying assumptions, see BL. Here I just summarize the restrictions of ID1, BL's benchmark identification scheme, in matrix notation, where stars denote unrestricted entries:

$$
B=\left(\begin{array}{lllll}
* & 0 & 0 & 0 & 0 \\
* & * & 0 & 0 & 0 \\
* & * & * & * & * \\
* & * & * & * & 0 \\
* & * & * & * & *
\end{array}\right), \quad L=\left(\begin{array}{ccccc}
* & * & * & 0 & 0 \\
* & * & * & * & * \\
* & * & * & * & * \\
* & * & * & * & * \\
* & * & * & * & *
\end{array}\right)
$$

Estimating the VECM with three cointegrating vectors and five lags in differences as BL do yields the results depicted in Figure 1 and 2: News shocks explain most of the variance of hours at any business cycle frequency beyond the first three quarters and they explain a gradually increasing share of $t f p$ variance. Also, news shocks generate strong positive responses of hours, much more so than surprise TFP or IST shocks. The second-most important shocks for hours seem to be non-technology shocks (monetary or non-monetary). BL show that these results are very robust across different choices of underlying variables, sample lengths and a broad range of identification schemes. 
Figure 1: FEVDs for BL's benchmark system, identification ID1
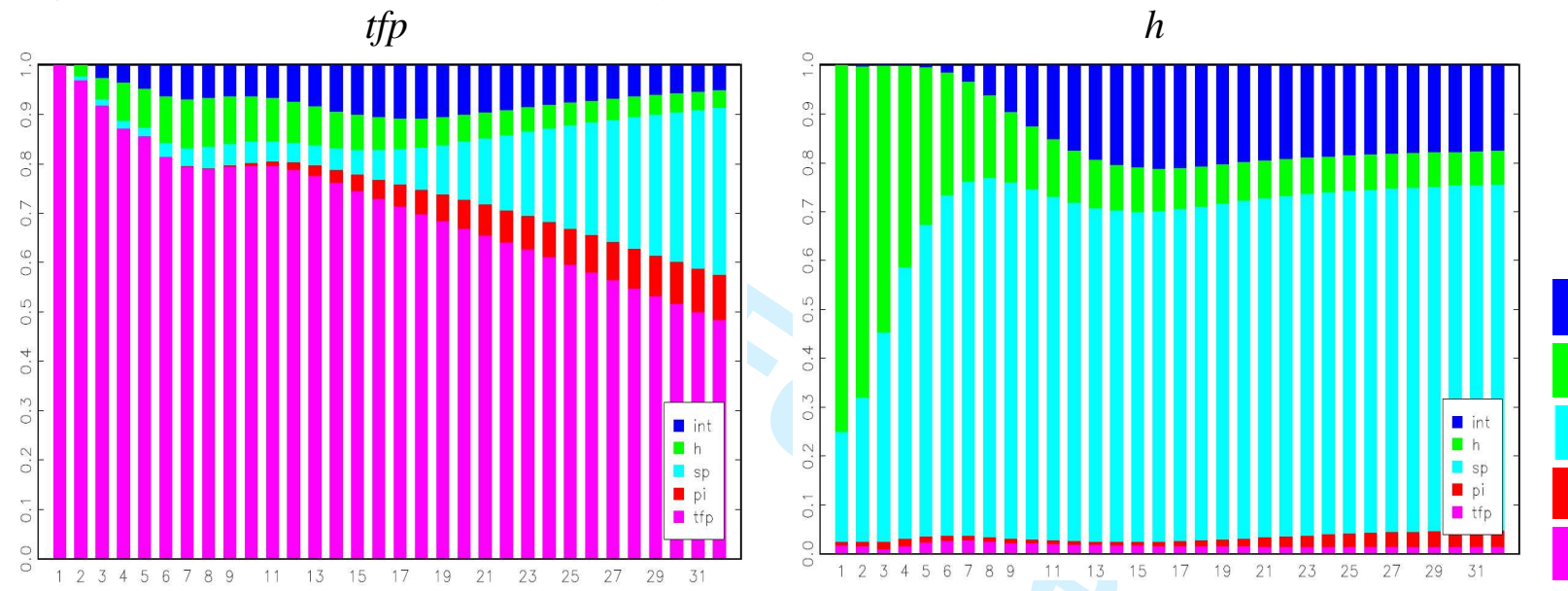

monetary shock preference shock news shock

surprise IST shock surprise TFP shock

Figure 2: Selected Impulse Responses for BL's benchmark system, identification ID1

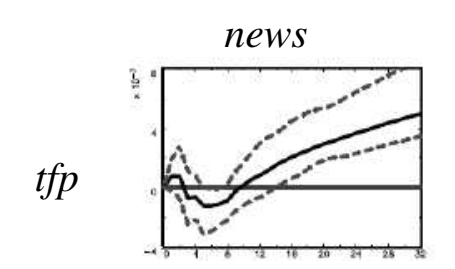

$h$
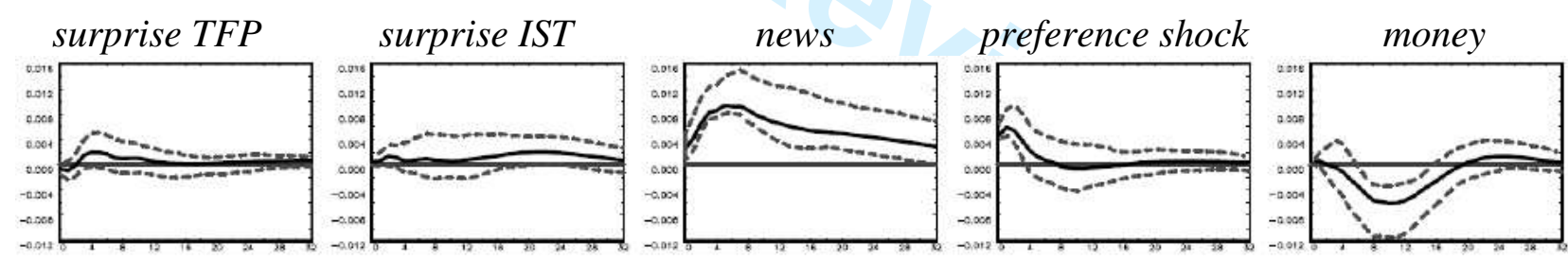

Impulses are given in columns, responding variables in rows. Solid lines are estimated impulse responses, dashed are two standard errors bootstrapped confidence intervalls (Hall) 
The type of evidence uncovered by BL seems to suggest that news shocks as a driving force of macro fluctuations are essentially technological. Since a significant effect of news on tfp becomes visible only after four years or more, one might speculate that news convey early information on inventions, $i$. e. at a point in time where substantial refinements and developments are still required to make the new technology efficiency enhancing. If this were true, news should trigger patents related to the basic invention. I will therefore test if the news shocks identified by BL are associated with a subsequent increase in the number of patents granted by the United States Patent and Trademark Office (USPTO).

I use the NBER U.S. Patent Citations Data File whose main features are explained in Hall, Jaffe and Trajtenberg (2001). The data set is weakly and covers 37 complete years (19631999). It includes all the utility patents granted during that period, totaling 2,923,922 patents. I extract two time series from this data base, one counting only those patents where the country of the first inventor is the US (series PATUS), a second one counting all granted patents (PATALL).

The patent data can, in principle, be aggregated to quarterly frequency to match the frequency of the structural residuals. It is, however, not clear whether it is reasonable to suppose that news shocks are related to the number of granted patents by some stable quarterly pattern. After all, the average total pendency, i. e. the average time from filing a patent application until the final decision by the USPTO, fluctuates between 25 and 31 months in recent years, i. e. in the range of two quarters. It is likely that similar fluctuations have occured throughout the sample. I therefore aggregate both the patent data and BL's structural shocks to yearly frequency, conjecturing that some regularity between news about technological innovations and the number of granted patents may be observed on an annual rather than a quarterly basis of observation.

While the average time for granting a patent is more than two years, patent applications are made public by the USPTO "promptly after the expiration of a period of 18 months from the earliest filing date", cf. USPTO (2008, p. 121). Thus, an invention must be considered public knowledge not later than 18 months after filing. Arguably, some people or industries with similar interests might know about it much earlier. Thus, the news about inventions will usually precede the granting of patents. On average, the first grant may be expected within less than a year after publication of the patent application and other, related patents probably follow with more or less delay. The precise timing, of course, depends on the nature of the invention, the research environment of the applicant and its competitiors and the speed of examination by USPTO, among others.

To test for Granger causality, I first estimate simple bivariate VARs in one of BL's structural residuals and one of the patent measures. I include a constant and a linear trend as deterministic variables. The conventional lag selection criteria recommend either one or two lags in almost all cases, hence, to be on the safe side, I estimate all VARs with two lags ${ }^{3}$. I use a Jarque-Bera test with Lütkepohl orthogonalization to test for non-normality of the VAR residuals and do not find any significant deviation from normality, neither for single equation residuals nor for joint tests. It may be worth emphasizing this result since the news shocks are retrieved from stock price data which often give rise to fat-tailed residual distributions.

\footnotetext{
${ }^{3}$ In a few cases, and only when the preference shock was involved, the recommended lag length was either two or three. I checked that estimating these systems with three rather than two lags did not change the results in any essential way.
}

Editorial Office, Dept of Economics, Warwick University, Coventry CV4 7AL, UK 


\footnotetext{
${ }^{4}$ Moreover, the structural shocks are not Granger-causal for each other, with the exception of the news and TFP shocks which seem to Granger-cause the preference shock. This result might indicate some serial cross correlation between structural errors which should be independent by construction. However, the seemingly significant statistics could also be a mere statistical artifact: Observe that the probability of a type I error is 5\% for a each single test and there are 25 tests of Granger-causal effects on the structural shocks for each patent variable.
} 
Thus, BL's news shocks seem to Granger cause US patent data. This supports their interpretation as news about technological advances. To make sure that this result is not possibly just a mere statistical artifact without economic significance, I now move on and repeat BL's analysis and the subsequent causality test for a different data set. The particular choice of country, Germany, was guided by the availability of patent data. (I have not done any kind of pre-test data checking on any other country (except the US)).

\section{A BL-type analysis for German data}

Technological news should not only affect US stock markets, but also affect the markets of other technologically advanced countries. Consequently, if all business cycles are alike, these countries should also reveal fluctuations in aggregate activity which are largely driven by shocks which simultaneously have a sizable explanatory potential for stock market data.

I now apply BL's identification strategy to German macro and stock market data. The focal point will be whether similar patterns as for the US data emerge, in particular a dominant contribution of news shocks to aggregate activity variance after 4-6 quarters and an increasing share of TFP variance explained by news shocks in the lower frequencies of the business cycle.

I use standard seasonally adjusted German macro data from the National Income and Product Accounts (NIPA), cf. Statistisches Bundesamt (2008). For data prior to 1970 I use the System of National Accounts of the German Institute for Economic Research (Deutsches Institut für Wirtschaftsforschung, DIW). In the first four years after German reunification (1990-1994), two separate systems of national accounting coexisted, one for the former West Germany, the other for unified Germany. I take the data for unified Germany for 1991-2008 and compute 
data for a fictitiously unified Germany prior to 1991 by applying the pre-1991 West German growth rates of each variable to the respective level in the first quarter of 1991.

I use real gross domestic product $y$, real gross private fixed investment $i$ and hours of the economically active population $h$ from Statistisches Bundesamt (2008), Tables 2.3.2 and 2.1.7. All variables are in logs and in per capita form using the population series in Table 2.1.6 from the same source. TFP data $t f p$ are constructed using $y, h$ and data on capital the capital stock $^{5}$ (Statistisches Bundesamt, series 111101). I multiply the capital stock by the capacity utilization rate in manufacturing drawn from the OECD's Main Economic Indicators, series 122961 DSA. The capital share is set at 0.30, the NIPA sample mean.

The inverse of the real price of gross private fixed investment $p i$ is the log-difference of the NIPA deflator for consumption and the respective NIPA investment price index. Real per capita stock prices $s p$ are derived as the log-difference between the main German stock price index (DAX), the population series and the NIPA consumption deflator. The data source for stock prices and short-run nominal interest rate (daily money rate in Frankfurt) is the German Central Bank (Deutsche Bundesbank, series WU3141 and ST0101, respectively). The sample size is $1966.1-2007.4$ for all variables.

Our first set of results is based on the five variable system consisting of $t f p$, $p i$, $s p$, an activity measure (either investment $i$ or output $y$ ) and int. The only deterministic series in the VAR is a constant. If the activity is $x$, we call this the NIPA_x system. Using Akaike's information criterion (AIC) to determine the appropriate lag length, two lags (in levels) are recommended for both NIPA_i and NIPA_y. Other lag length selection criteria (e. g. Schwarz, HannanQuinn, Final Prediction Error) also recommend two or even fewer lags and thus just one lag in differences. As this seems to be a very parsimonious specification for quarterly data, I estimate the system in differences with one additional lag, i. e. two lags. While this is not the optimal choice in terms of information criteria, the estimate is consistent if the true lag length is indeed one (in differences). Moreover, the additional lag increases the likelihood that all relevant autocorrelation in the data is captured in the systematic part of the vector autoregression.

Turning to cointegration properties, one might expect from theory that the NIPA systems are driven by two stochastic trends representing disembodied and investment-specific technical progress. Johansen tests for cointegration, however, find only two cointegrating vectors for NIPA_i and NIPA_y. To make my results as much as possible comparable with BL's, I assume the existence of a third cointegrating vector. Moreover, this fits well with the idea of two stochastic trends in all systems. As compared to the alternative assumption of two cointegrating vectors my treatment leads to a more general specification of short-run dynamics since the VECM will have a third error correction term (whose loading coefficient may be estimated as zero if this error correction term is unimportant). On the other hand, the specification is less general in terms of the long-run properties, since the long-run multiplier matrix is restricted to have rank two with three cointegrating vectors rather than rank three with two cointegrating vectors. Given the considerable structural change in the sample (German reunification 1990, introduction of the Common European Market in 1992, introduction of European Monetary Union in 1999) it seems reasonable to have the choice of long-run equilibrium properties guided by theoretical considerations rather than taking data properties at face value.

\footnotetext{
${ }^{5}$ Capital stock data are available only at annual frequency. They are converted to quarterly data assuming constant growth rates in each year.
} 
I proceed by estimating a vector error correction model (VECM) for the NIPA_i system, which will be my benchmark. Note that BL took hours as the activity measure for the benchmark system, but this seems not advisable for German data, since the highly regulated German labor market gives rise to sizable labor hoarding behavior. Thus hours (a series with a strongly negative trend in German data) are likely to be a distorted and thus inadequate measure of economic activity. The converse is true for output but I prefer investment as the benchmark measure since $t f p$ is a residual of the output series and this typically affects the results of variance decompositions in the sense that a certain share of output variance tends to be explained by TFP shocks by construction. Nevertheless, results for NIPA_y will be given as a robustness check.

\section{a) Identification ID1}

I begin by estimating a structural decomposition of the $\mathrm{VECM}^{6}$ using identification scheme ID1. The variables are ordered as $t f p, p i, s p, i$, int. I compute impulse responses (IR) and forecast error variance decompositions (FEVD).

The FEVDs, cf. Figure 3, show the contributions of the identified structural shocks to the forecast error variances of each dependent variable over a business cycle horizon of 32 quarters. In discussing the results, I refer to the shocks as the surprise TFP, surprise IST, news, preference and monetary shock.

The most interesting findings from the FEVDs are the following: First, the two major shocks for investment are the news shock and the preference shock. Together they account for more than $70 \%$ of investment variance across all horizons. The preference shock is most important for short horizons while the news shock dominates the long business cycle horizons, where, eventually, it becomes more important than all other shocks taken together. Monetary shocks are unimportant. Surprise TFP shocks contribute about $20 \%$ of investment variance on impact and gradually less as time goes by. Surprise IST shocks explain a relatively constant share of roughly $15 \%$ of investment variance for horizons longer than two years but are unimportant on impact. Note that these results are very similar to BL's results for NIPA_i. The main difference is that the variance share explained by the TFP shock is almost zero on impact in the US data (and gradually increasing). For longer horizons, however, the investment FEVDs of German and US data are surprisingly similar.

Second, stock prices are almost exclusively driven by the news shock, even more than in the analogous FEVD of BL. It is remarkable that "fundamentals" as represented by surprise TFP and IST shocks seem to be mostely unimportant for stock prices. TFP shocks do not play any role at all and the importance of IST shocks is limited a little over 10\% at the long end of the business cycle horizon. This suggests that most technological innovations are known to stock market traders before they are actually implemented. Third, the FEVDs in fact show that news shocks contribute up to $50 \%$ of the variance of $t f p$ at business cycle horizons, and this share increases further as time goes by, for instance, it is $70 \%$ after 15 years. Again, this finding is essentially the same as in BL. But unlike in the US data the German news shock seems to also have a (still somewhat tiny) long run effect on the IST measure, where it explains about $20 \%$ of the variance after eight years and more at even longer horizons.

Impulse responses in Figure 4 display the responses of each dependent variable row-wise with the columns representing the shocks. Responses are given for the first 32 quarters.

\footnotetext{
${ }^{6}$ I use the free Jmulti software, cf. www.jmulti.de.
} 
Contractionary monetary policy shocks seem to have a temporary negative effect on investment as typically documented elsewhere in the literature. The effect sets in gradually, peaks after about two years and then phases off back to zero. The effect is small, however, relative to the responses to other structural shocks.

Preference shocks cause positive responses of investment and interest rates for about two years. News shocks seem to convey information about both TFP and IST growth that starts one or two years in the future. (BL found a similar result for TFP but not for IST.) Also, news shocks cause an expansion of investment not later than a year after the shock. (The point estimate is positive on impact, but significantly positive only after a year.) The long run effects of news shocks seem to be permanent. IST shocks also cause seemingly permanent effects on all variables (including, possibly, tfp), which is in line with my assumption that IST is a second stochastic trend of this system. By contrast, surprise TFP shocks seem to generate only temporary effects. This is what is to be expected if main technological advances manifest themselves as news shocks rather than as surprises.

I now move on to output as an alternative measures of activity, i. e. I replace investment by output as a robustness check. Selected results are displayed in Figure 5 and Figure 6. News shocks play a similar role in the variance of $t f p$, both qualitatively and quantitatively, as they do in NIPA_i. They account for somewhat less of stock price variance than in NIPA_i, but their share is still very large (about $80 \%$ ). They again explain an increasing share of output variance which becomes fairly large at long horizons (more than $60 \%$ at 32 quarters). This is almost the same magnitude as in NIPA_i for the variance of investment. In the short run the share of activity variance explained by surprise TFP shocks is quite a bit larger in NIPA_y than in NIPA_i (and the share of the preference shock is smaller). This is probably due to the fact that TFP is computed as a residual from the output series. IST shocks are fairly unimportant, but preference shocks are not, where the latter, again, have higher explanatory potential in the short run. Output variance explained by monetary shocks is negligible.

Turning to selected impulse responses given in Figure 6, we can see that, again, news shocks seem to have a strongly significant positive long-run effect on tfp. Moreover, news shocks have significant positive effects on output as the activity measure. The effect may set in immediately, possibly because the availability of a new technology requires resource usage for implementation and reorganisation. It becomes significant after about a year. Surprise TFP shocks have some, possibly only transitory, effect on output. This effect as well as the effect of preference shocks is more important in the short run than in the long run. Contractionary monetary policy shocks cause a tiny, marginally significant negative reaction of output which has the typical shape of an activity response to monetary policy shocks. 
Figure 3

FEVDs of the NIPA_i System, identification ID1
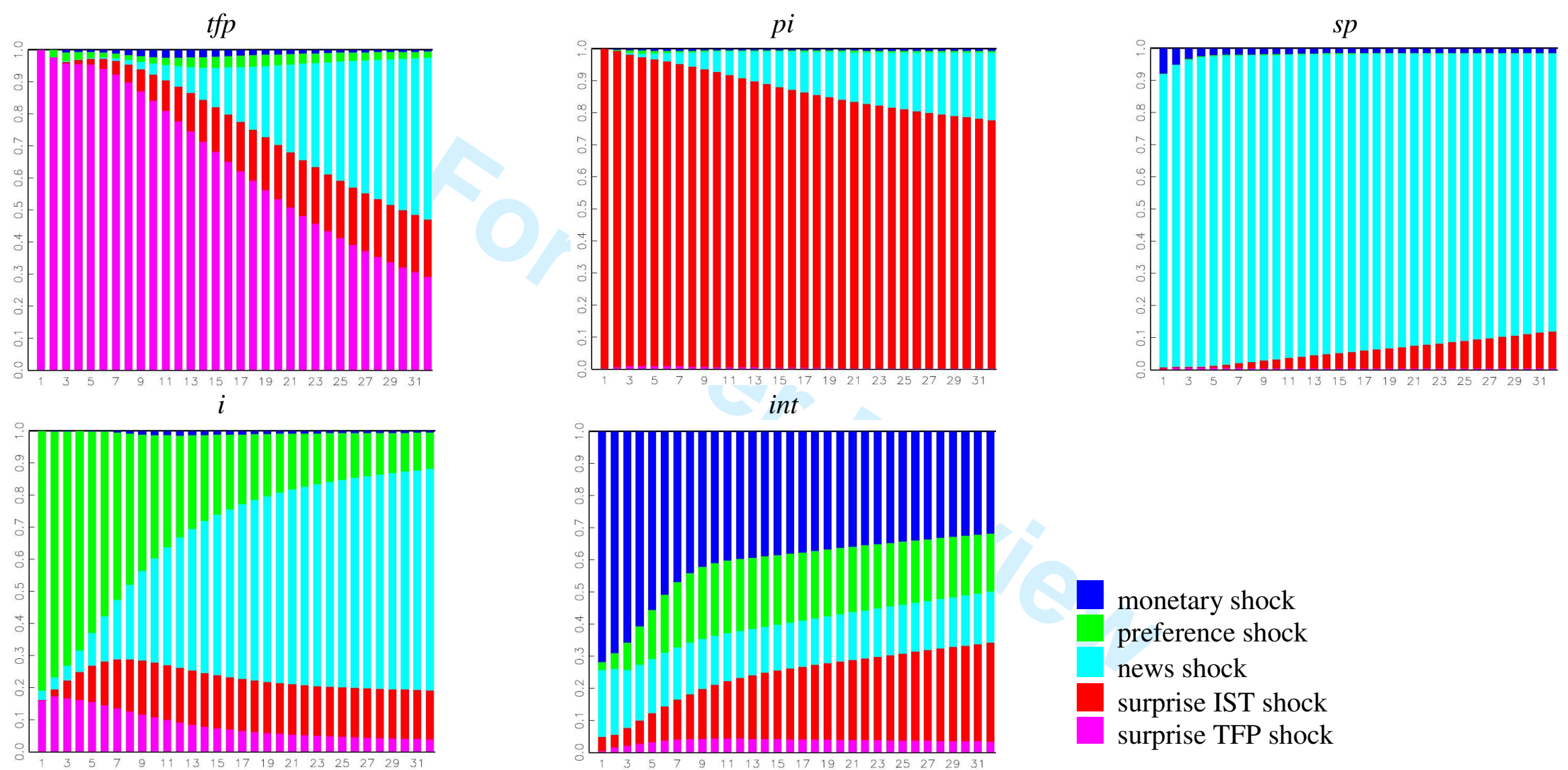

monetary shock

preference shock

news shock

surprise IST shock

surprise TFP shock 
Figure 4: Impulse responses of NIPA_i, identification ID1

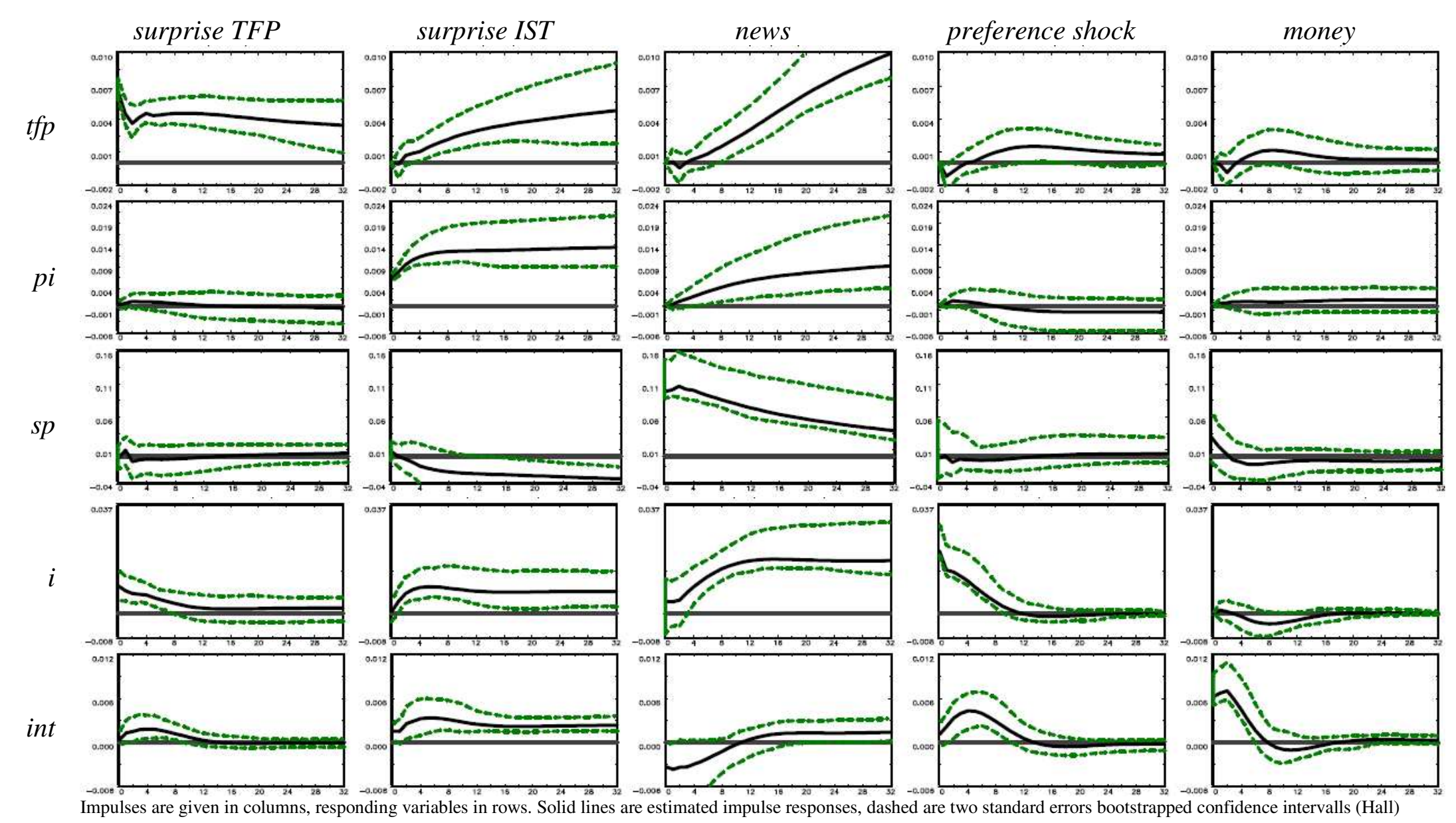

Editorial Office, Dept of Economics, Warwick University, Coventry CV4 7AL, UK 
Figure 5

Selected FEVDs of variables in NIPA_y, identification ID1
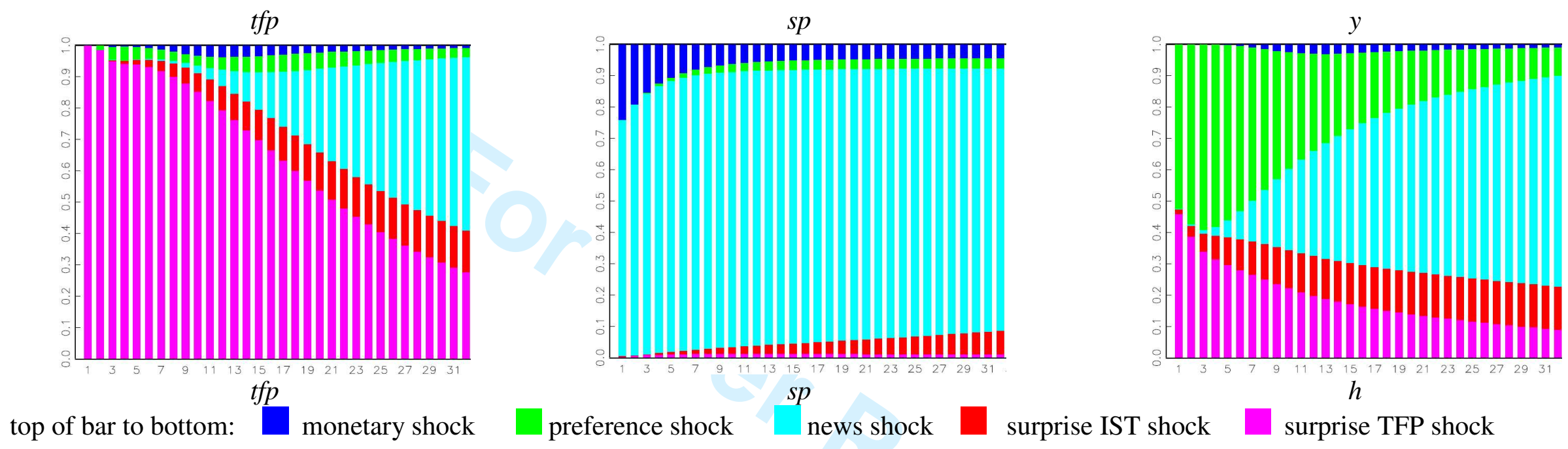

top of bar to bottom:

monetary shock

preference shock news shock

surprise IST shock

surprise TFP shock

Figure 6: Selected Impulse Responses for NIPA_y, identification ID1

Responses of TFP (columns 1-2) and Activities (columns 3-6) to shocks indicated on columns

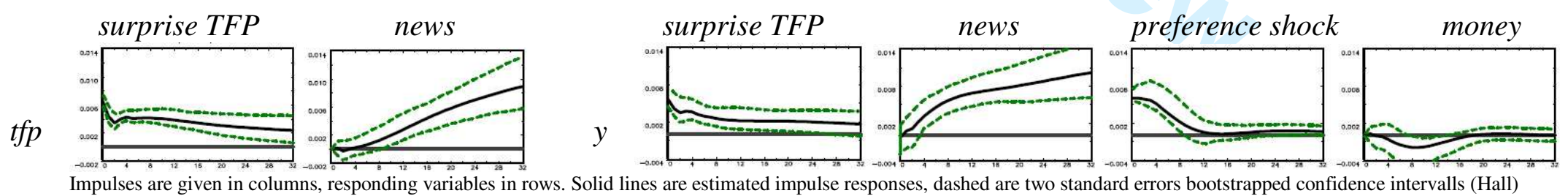

Editorial Office, Dept of Economics, Warwick University, Coventry CV4 7AL, UK 
BL study an alternative identification scheme which relies more on long-run restrictions than ID1. The reasoning is that the relative price of investment may not be an appropriate measure of IST if the economy is subject to certain short-run frictions such as investment adjustment costs. It is therefore desirable to lift the restrictions in the second row of $B$ and impose three additional restrictions on the long-run matrix $L$ instead. They therefore suggest an identification scheme ID2 with the following properties:

$$
B=\left(\begin{array}{ccccc}
* & 0 & 0 & 0 & 0 \\
* & * & * & * & * \\
* & * & * & * & * \\
* & * & * & * & 0 \\
* & * & * & * & *
\end{array}\right), \quad L=\left(\begin{array}{ccccc}
* & 0 & * & 0 & 0 \\
* & * & * & 0 & 0 \\
* & * & * & * & * \\
* & * & * & * & * \\
* & * & * & * & *
\end{array}\right)
$$

I will not discuss the reasoning behind this set of restrictions but rather refer the interested reader to BL. For the German data set, a structural decomposition of the benchmark system NIPA_i using identification scheme ID2 leads to results very similar to those obtained under ID1, cf. Figures 7 and 8. The main (but inessential) differences are that under ID2 the news shock does not explain almost $100 \%$ of stock price variance but typically something around $70 \%$, with the rest of the variance being attributed to the surprise IST shock. In the variance of investment, however, the IST shock is less important under ID2 than under ID1, in fact, it is negligible. The explanatory power of the news shock for investment variance is even larger under ID2 than under ID1.

For NIPA_y I also find qualitatively the same results under ID2 as under ID1. (To save space, these are not given in the paper, but available upon request.) Hence the analysis of the German sample not only delivers much the same type of results as the analysis of the US sample, is also seems to be similarly robust with respect to different identification schemes. 
Figure 7

FEVDs of variables in NIPA_i, identification ID2
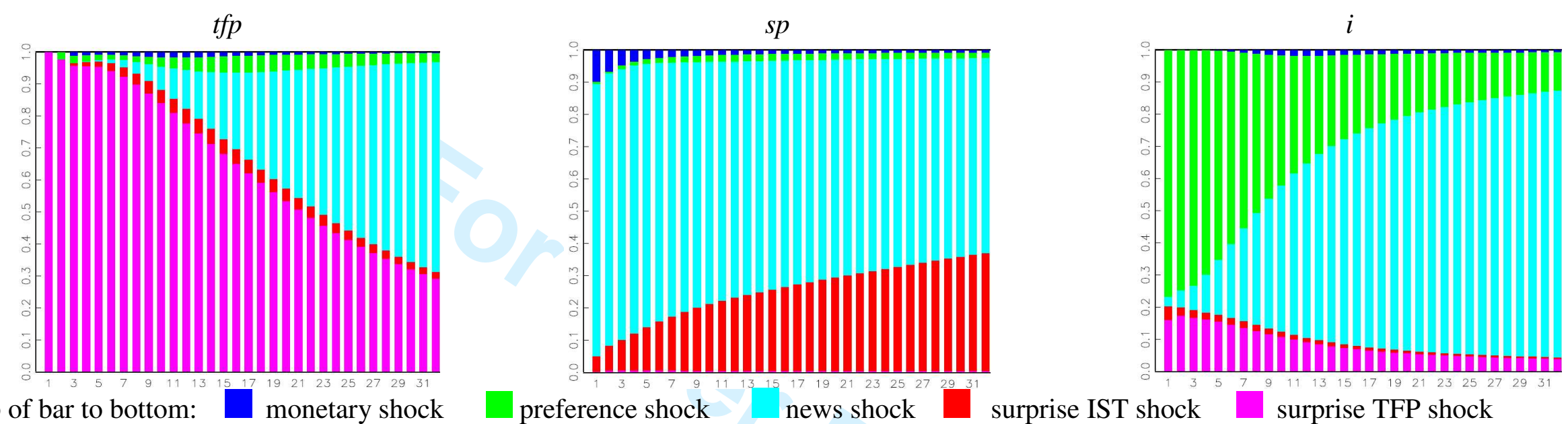

top of bar to bottom:

preference shock news shock

surprise IST shock

surprise TFP shock

Figure 8: Selected Impulse Responses for NIPA_i, identification ID2

Responses of TFP (columns 1-2) and Investment (columns 3-6) to shocks indicated on columns

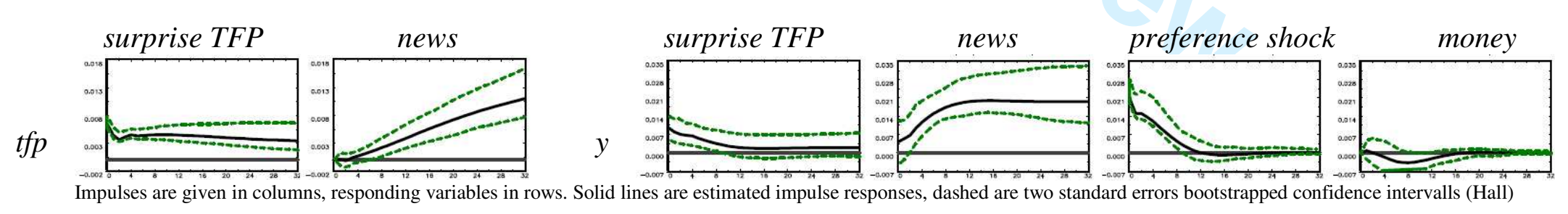

Editorial Office, Dept of Economics, Warwick University, Coventry CV4 7AL, UK 
Again, it is an open issue when exactly technological innovations become publicly known. By German law, however, any invention which seeks patent protection has to be described in the patent application which must be sufficiently detailed to be understood by a knowledgeable person. The patent agency will publish the patent application not later than 18 months after it has been submitted. This usually happens before a decision has been reached and a patent is granted or refused. Hence, technological innovations are, in general, publicly known before a patent is granted.

The natural hypothesis to test for is thus a possibly causal effect of news shocks on granted patents. Reverse causality (from patents to news) should not exist, since the patent applications (with technical descriptions) are typically known before the patent agency decides on granting a patent.

Since the patent data are available only in yearly frequency, I aggregate the structural shocks identified in the benchmark NIPA_i system by summing the quarterly values to annual frequency. I then estimate bivariate VARs for one of the two measures of granted patents and one of the five structural shocks indentified in the benchmark NIPA_i under identification ID1. The lag length of the VARs is data-determined by the Akaike information criterion. With very few exceptions, the lag length is one in the bivariate VARs.

Table 3 contains the results of this exercise. I find that both the IST shock and the news shock seem to Granger-cause patents. No other structural shock does, nor is there evidence of reverse causation. Exactly the same results are obtained if the structural shocks from NIPA_y are used. The P-values of the significant statistics are even lower for these shocks, e. g. the effect of news shocks on PATGALL is significant in this case ${ }^{7}$. Thus, in sum, both news and IST shocks seem to Granger-cause granted patents in Germany. For the news shocks, it is

\footnotetext{
${ }^{7}$ Results for NIPA_y are suppressed in the paper but are available upon request.
} 
remarkable that this is the same type of result as found in the US data. For IST shocks there is no analogous finding for the US, but the result itself is, of course, quite plausible, as surprise advances in embodied technology should typically also give rise to subsequent grants of patents.

Multivariate VARs comprising one of the patent measures and all of the structural shocks lead to the same conclusion, cf. Table 4. The news shock and the IST shock are found to be Granger-causal for both patent measures even if many other possibly explanatory variables are at hand. With one exception all other statistics are insignificant at the 5\% level. The exception is truely an exception because this statistic is not significant if NIPA_y residuals are used. However, the Granger-causal effect of news and IST shocks is consistently found also if these alternative measures of structural shocks are used, while no other statistic is significant in the NIPA_y case.

\begin{tabular}{|l|l|l|l|l|l|l|}
\hline \multicolumn{5}{|c|}{ Table 3 } \\
\hline & $\begin{array}{l}\text { TFP } \\
\text { shock }\end{array}$ & $\begin{array}{l}\text { IST } \\
\text { shock }\end{array}$ & $\begin{array}{l}\text { News } \\
\text { shock }\end{array}$ & $\begin{array}{l}\text { Preference } \\
\text { shock }\end{array}$ & $\begin{array}{l}\text { Money } \\
\text { shock }\end{array}$ & $\begin{array}{l}\text { PATGG } \\
\text { PATGALL }\end{array}$ \\
\hline & & & & & & 0.522 \\
& & & & & 0.720 \\
\hline TFP shock & & & & & 0.000 \\
\hline IST shock & & & & & 0.005 \\
\hline News shock & & & & & 0.023 \\
& & & & & & 0.060 \\
\hline $\begin{array}{l}\text { Preference } \\
\text { shock }\end{array}$ & & & & & 0.828 \\
\hline Money shock & & & & 0.818 \\
\hline $\begin{array}{l}\text { PATGG } \\
\text { PATGALL }\end{array}$ & 0.165 & 0.375 & 0.732 & 0.191 & 0.700 & 0.341 \\
\hline $\begin{array}{l}\text { Note: Each VAR consists of one of NIPA_i's structural shocks and either PATGG or PATGALL. Given are the P-values } \\
\text { for the null hypothesis that the row variable does not Granger cause the column variable. The first entry in each cell refers } \\
\text { to the VAR with PATGG, the second to the VAR with PATGALL. }\end{array}$ \\
\hline
\end{tabular}




\section{Conclusions}

The recent empirical literature on news shocks has tried to identify news from stock price data since the stock market is forward looking and probably highly efficient. However, almost any kind of news may affect stock prices and thus there is a priori no compelling reason to suppose that news are predominantly technological.

BL have presented some evidence which suggests that news explain an increasing share of TFP variance at long horizons. Based on this finding they conjecture that news shocks are mostly technological. This paper contributes three additional pieces of evidence which supports their interpretation: First, US news seem to be Granger-causal for increases in the number of granted patents. This matches well with the idea that news are news about inventions which give rise to various developments and appliances temporarily protected by patents. Second, structural decompositions of German macro data also uncover shocks which dominate stock market variance, explain a major share of activity variance and affect t $f p$ with a sizable lag. The most suggestive interpretation of a shock with such properties seems to be a technological news shock. Third, the identified German news shocks Granger-cause German patent data in much the same way as US news shocks affect US patent data. Since the patent data series are virtually uncorrelated between the US and Germany, the Granger causality tests seem to be two independent pieces of evidence which lead to the same conclusion: News shocks are predominantly technological. 


\section{References:}

Amisano, G., and Giannini, C., (1997): Topics in Structural VAR Econometrics, $2^{\text {nd }}$ edition, Springer Verlag, Berlin.

Bagliano, F. C., Favero, C. A. (1998): Measuring Monetary Policy with VAR Models: An Evaluation, European Economic Review 42, pp. 1069-1112.

Beaudry, P., and Lucke, B., (2010): Letting Different Views about Business Cycles Compete, NBER Macroeconomics Annual, pp. 413-455.

Beaudry, P., and Portier, F., (2006): Stock Prices, News and Economic Fluctuations, American Economic Review, Vol. 96, pp. 1293-1307

Beaudry, P., and Portier, F., (2007): When can changes in expectations cause business cycle fluctuations in neo-classical settings?, Journal of Economic Theory 135(1), pp. 458477.

Blanchard, O. J., and Kiyotaki, N. (1987): Monopolistic Competition and the Effects of Aggregate Demand, American Economic Review 77, pp. 647-666.

Blanchard, O., and Quah, D., (1989): The Dynamic Effects of Aggregate Demand and Aggregate Supply Disturbances, American Economic Review 79, pp. 655-673.

Christiano, L. J., Eichenbaum, M., and Vigfusson, R., (2004): The Response of Hours to a Technology Shock: Evidence Based on Direct Measures of Technology, NBER Working Paper 10254.

Cummins, J., and Violante, G., (2002): Investment-Specific Technical Change in the United States (1947-2000): Measurement and Macroeconomic Consequences, Review of Economic Dynamics 5, pp. 243-284.

Fisher, J. D. M., (2003): The Technology Shocks Matter, Federal Reserve Bank of Chicago WP 2002-14, December 2003.

Fisher, J. D. M., (2006): The Dynamic Effects of Neutral and Investment-Specific Technology Shocks, Journal of Political Economy 114, pp. 413-451.

Galí, J., (1999): Technology, Employment, and the Business Cycle: Do Technology Shocks Explain Aggregate Fluctuations?, American Economic Review 89, pp. 249-271.

Gordon, R., (1989): The Measurement of Durable Goods Prices, Chicago, University of Chicago Press.

Greenwood, J., Hercovitz, Z., Krusell, P. (1997): Long-Run Implications of InvestmentSpecific Technological Change, American Economic Review, Vol. 87, No. 3, pp. 342362.

Haertel, T., Lucke, B., (2008): Do News Shocks Drive Business Cycles? Evidence from German Data, Economics: The Open-Access, Open-Assessment E-Journal, Vol. 2, 2008-10. http://www.economics-ejournal.org/economics/journalarticles/2008-10

Hall, B. H., Jaffe, A. B., Trajtenberg, M., (2001): The NBER Patent Citations Data File: Lessons, Insights and Methodological Tools, NBER Working Paper 8498.

Jaimovich, N. and Rebelo, S., (2009): Can News About the Future Drive the Business Cycle?, forthcoming American Economic Review.

Jungmittag, Andre and Grupp, Hariolf (2006): "Dynamic Relationships Between Innovation Activities and per Capita Income in Germany 1951-1999 in Comparison to 1850-1913", Jahrbücher für Nationalökonomie und Statistik, Band 226, Heft 2, pp. 180-207

Lucke, B., (2008): Identification and Overidentification in SVECMs, Discussion Paper, University of Hamburg.

Peretto, P. F., (1996): Sunk Costs, Market Structure and Growth, International Economic Review, 37(4), pp. 895-923.

Statistisches Bundesamt (2008): Volkswirtschaftliche Gesamtrechnungen, Fachserie 18, Reihe S.28, Wiesbaden. 
USPTO (2008): Manual of Patent Examining Procedure, Appendix L, Patent Laws, $8^{\text {th }}$ edition 2001, latest revision July 2008, United States Patent and Trademarks Office. 